\title{
"A Portrait of the Artist as a Female Painter": the Kunstlerroman Tradition in A. Banti's Artemisia
}

The salient traits of the life of Artemisia Gentileschi, a seventeenth century Italian painter and follower of Caravaggio, are easy to put together. In the preface of her novel, Artemisia, which is a fictional recreation of this artist's life, Anna Banti offers a number of precise chronological remarks: "Nata nel 1598, a Roma, di famiglia pisana. Figlia di Orazio, pittore eccellente. Oltraggiata, appena giovinetta, nell'onore e nell'amore. Vittima svillaneggiata di un pubblico processo di stupro. Che tenne scuola di pittura a Napoli. Che s'azzardò, verso il 1638, nella eretica Inghilterra. Una delle prime donne che sostennero colle parole e colle opere il diritto al lavoro congeniale e a una parità di spirito tra i due sessi" (preface). ${ }^{1}$ A historical revision of this painter's life and accomplishment has many times been attempted in the wake of the queer fame surrounding her adolescence. Critical attempts to objectively separate fiction from fact, gossip from truth, however, are starting to be successful only now that a new wave of feminist art historians is engaged in demythologizing the artistic canon. For many years, even after the extensive studies of Hermann Voss and Roberto Longhi, a number of hostile critics have deliberately underrated the merits of Gentileschi the artist while stabbing Gentileschi the woman with mysoginist malevolence. The difficulty in assessing the worth of this painter comes from the fact that Gentileschi was an unconventional person in an age when females were rarely allowed to stray beyond their prescribed boundaries. For a woman to achieve fame and acclaim after being the subject of ridicule of an entire city was unheard of at the beginning of the seventeenth century, and perhaps still is peculiar in our times. Unfortunately, both life and literature often show how artistic distinction is jeopardized or minimized by sex biased judgments. 
The purpose of the fiction writer is not to mirror reality. In Artemisia, while keeping close to the chronological data, Anna Banti allows herself freedom from linearly biographical information when history does not fit her characterization. She can be trusted, however, in her reconstruction. Besides being a fiction writer, Banti is an accomplished art critic and a careful researcher of Caravaggio and his followers. ${ }^{2}$ Her clever use of a historical framework both dramatizes and universalizes the struggle of her protagonist against a chauvinistic seventeenth century environment, one which too often made scapegoats of women or blurred their sense of self-worth. "Accostarsi all'universo femminile attraverso il diaframma dei secoli," Anna Nozzoli writes, "sarà dunque per la Banti qualcosa di piú e di diverso del semplice repêchage storico e della ricerca erudita, un modo di recuperare lo stato d'inferiorità della donna nel momento individuale e nel valore esemplare" (87). My purpose in this paper is to analyze a few phases of Maestra Gentileschi's personal and creative growth from her tormented adolescent years to her discovery of a pictorial talent, and from the various crises and failures which studded her life to the final reassertion, in later years, of her female identity. I will also make references to two paintings which-both in reality and in Banti's fiction-thoroughly inscribe Artemisia's struggle: "Judith beheading Holofernes," now at the Uffizi in Florence, and "La Pittura," or "Self-Portrait," at Kensington Palace in London.

Artemisia covers roughly forty years of narrational life. It can be read, however, as an extended bildungsroman, or, to be more specific, as a Kunstlerroman, since its subject is the formation of an artist. The novel of growth and apprenticeship to life typically deals with a single, central male character. The protagonist is first followed through the years of self-awakening and subsequent search for autonomy from established familial and societal rules. Then comes the chronicle of his shedding of youthful illusions, the path to solitude and intellectual alienation being inevitably trodden, and a mature, possibly harmonious personality often displayed at the end. When a female character is the focus of a bildungsroman, a subtle change in focus takes place. Intellectual growth becomes of secondary importance and scholastic skills are too often bypassed. What is described instead is the effort made to prepare her to reach not a personal goal of self-definition but two other goals defined for her: the social 
one of marriage and the biological one of motherhood. No matter what particular aspirations in life a woman might have, her full integration into society becomes possible, it seems, only through her polishing of nurturing, self-abnegating qualities. To paraphrase Annis Pratt, women grow up and then, by fitting themselves into their expected slot, they grow down. In the last few years, however, feminist authors are using the female bildungsroman as a tool to express women's awakening to new roles and to cultural and social explorations beyond traditionally allotted limits. "The feminist bildungsroman," Bonnie Hoover Braendlin writes, "delineates woman's self-development toward a viable present and future existence, free from predetermined, male-dominated societal roles, which in the past have yielded a fragmented rather than a satisfactorily integrated personality" ("Alther" 18). ${ }^{3}$

It is necessary to qualify the term bildungsroman as it applies to Artemisia. If anything, the concept of education as a pre-ordained task the young protagonist undergoes in order to grow is totally absent from the novel. Nothing is further from the mind of Orazio Gentileschi than the formal education of his daughter. Artemisia never learns to write correctly and, according to Banti, has to make frequent use of scribes for her official correspondence. Nor is Artemisia educated to be financially independent in her maturity, trained to translate, for example, her artistic gifts into economic support. Structured education was uncommon for men in the seventeenth century and definitely rare for women. Yet, Artemisia has one advantage over the majority of her contemporaries. Orazio has her learn the laws of drawing and perspective at fourteen, under the direction of fellow painter and famous bon vivant Agostino Tassi. ${ }^{4}$ The desire to train his daughter in the visual arts is not prompted in the father by any personal acknowledgement of Artemisia's precocious talent. He is aware, rather, that he has to find another way to use her skills because the young woman is swiftly outliving her modeling days and will soon be unable to pose as an angel for his canvases. Moreover, Orazio thinks that plain working habits will better keep his daughter under control. Artemisia has a vivacious and extroverted personality, a nature which combines the impetuosity of the tomboy with the restlessness of the motherless child and which, therefore, lends itself to be misinterpreted by friends and neighbours 
alike. To compound the problem, the girl lives in a household where many male artists freely come and go, a situation which can easily create a moral vacuum or obliquely taint a woman's reputation. In the Gentileschi's lodgings there are no female relatives or friends to tutor Artemisia in conventional feminine survival skills or to introduce her into the marketable world of sexual politics. Artemisia's mother is dead; of her two other ersatz mothers who lived in the family at some point, both have abandoned her. For all practical purposes, Artemisia is not once, but thrice orphaned. Tuzia, a neighbour burdened with children and poverty, has lately been asked by Orazio to shelter and supervise his daughter's social and sexual vulnerability. Tuzia, however, seems to play the role of the madam rather than that of the counselor, and Artemisia openly mistrusts her. We are only ten pages in the narrative and already can guess accurately what will come next. When a fourteen-year-old motherless girl living with an absent and often uncaring father and a loose companion is asked to study painting skills with a previously-convicted womanizer, we can predict that she is destined to learn "other" skills. This is such a common plot in literature that even casual readers of novels can decipher it. Seduction and betrayal are too often part of the female destiny; the metaphor of initiation as a process of disillusionment and subsequent isolation too often translates into reality for women. With Moll, Clarissa and Tess, Artemisia shares an identical rite of passage, a comparable initiatory ordeal. "Quattordici anni!" she querulously recounts; "Mi difesi e non valse. Aveva promesso di sposarmi, lo prometteva fino all'ultimo, traditore, per togliermi la mia vendetta" (22). ${ }^{5}$ Loss of innocence is, of course, the natural theme of any novel of apprenticeship; the relinquishing of dreams constituting the necessary step for a young individual to move from ignorance to understanding and, in the process, to grow. In Artemisia the loss is not only irrecoverably physical, but also mortifying from a psychological point of view. Rape both violates the young woman's body and castrates her social life. In a restrictive patriculture a seduced woman loses her worth as a commodity, is shunned by friends and seen as a social embarrassment by relatives. To make matters worse, if such a woman undergoes a public trial and is both examined and tortured with thumbscrews in the papal and autocratic Rome of 1611 , it is clear that there is 
no chance for her social redemption, no normal future within her antagonizing environment. She becomes a target of ridicule, a social outcast, a freak. Along with her forfeited virginity and faded Cinderella dreams, Artemisia loses the positive image of herself as a growing woman and promising artist: "Donna, inferno per me, male per gli altri." At the same time, in an environment where women are the official property of men, one can understand why a wronged father would sue his daughter's seducer for having deprived him of the face value of his assets through his careless, untimely appropriation (Clark and Lewis, $115 \mathrm{ff}$.). It can easily be imagined what becomes of a daughter if marriage, as it is the case here, becomes impossible. The humiliation at the public exposure immobilizes in metonymical fashion Artemisia's present and encloses her within the mortifying, solitary role of the "lost" woman. Through Artemisia, Anna Banti properly eulogizes hundreds of women whose destinies are doomed or vilified by a sexual catastrophe: "La nostra povera libertà si lega all'umile libertà di una vergine che nel milleseicentoundici non ha se non quella del proprio corpo e non può capacitarsi in eterno di averla perduta" (26). Time and again-and to no avail-Artemisia tries in the narrative to alter a past which refuses to be denied, or strives with touching naivete to re-enter the prelapsarian state from which she felt she was forced to depart too soon. ${ }^{6}$

At first, as one would expect in a girl endowed with an assertive and brilliant personality, Artemisia refuses to let herself be transformed into a passive heroine just to qualify for the pity and understanding of her neighbours. Since she is rejected as a "proper" woman, she feels disenfranchised from social constrictions and decides to move about as a man: "Io dissi, vado da me; allora mi pareva che dopo la vergogna avevo almeno il diritto di essere libera come un uomo" (28). Unfortunately her supercilious environment, unaccustomed to androgynous models, does not know what to do with such a person and rejects her again. ${ }^{7}$ Economically vulnerable, socially castigated, and psychologically confused, Artemisia then gives free rein to her destructive and claustrophobic penchant and immures herself into her father's somber apartment. The text is saturated with images of isolation, entrapment, and self-burial. These metaphors are usually present in the bildungsroman, but in this novel they accrue with nihilistic inevitability. Artemisia starts to dress in black, 
further obliterating her sex: "durasse per sempre il buio, nessuno mi riconoscerebbe per donna" (32). She accuses herself of unwanted complicity in her painful experience and feels superfluous to her environment. As depression sets in, she retreats from dreams of grandeur and ambition for success, and hopes for oblivion. Her features acquire the pallor of the recluse; the huge, austere kitchen of the Gentileschi's household turns into a round-the-clock trap. There she lets the windows remain hermetically closed throughout the day to better foster an inner sense of self-castigation, only to throw them open at night to literally gasp for air. To oxygenate this asphyxiating, self-denying world, Artemisia can only hope for a few short conversations late at night with her brother who, unlike her, has the freedom to move in artistic circles and the chance to follow his interests.

Yet the locus of claustration becomes in time the place of initiation. It is in these enclosed spaces that Artemisia slowly exorcizes her misandry by refining her skills. Thus she onomastically renames herself through paper and pencil: Arte(misia). Her initial subjects for drawing are inanimate, fragmented items ingeniously combined: fruits, flowers or a skull. Then one day she draws a more emblematic figure, a one-winged dove resembling the wing of an angel. The image of the maimed or caged bird is often used by women writers to visualize the metaphorical prison in which their characters find themselves psychologically shut. Crippled as a woman, abandoned as a daughter ("Tuo padre ... non ti voleva vedere"), and exiled as a human being, Artemisia reveals in this sketch both her desire to reach exhilarating heights and an inner fear of falling. Her drawing takes on a meaning still more important: it is while she perfects the bird that famous Orazio finally acknowledges his daughter's creative skills. One evening he leans over her work, looks carefully and then nods in appreciation. His smile is the necessary therapy for an adolescent who has lived for years in constant paternal awe and has waited neurotically for his forgiveness. Now she pleases him by emulating his craft. That same evening, drunk with joy, Artemisia flings a window open and sees swallows soaring high, the metonymic illustration of her fluttering spirits.

The epiphanic moment of non-verbal communion with Orazio is succeeded by a radical change in this artist's life. The moment of re- 
birth just described, a typical one in the bildungsroman, ends the first phase of Artemisia's personal growth. She is not only aware now of her artistic potential, but can even project herself toward a future where her inclinations can be publicly pursued. Banti emphasizes Artemisia's self-discovery after months of death-in-the-life through a change of locale and a consequent exteriorization of her intimate journey. That same night Orazio announces his intention to take his daughter along with him to Florence where he plans to relocate. To reject her city of negation and all that is connected with it, Artemisia literally throws some of her belongings out of the window. In the new city Orazio quickly renounces his Pygmalion role and moves to Pisa. Artemisia finds herself again devoid of masculine "protection" and as lonely and insecure as before. This makes her plunge into physical withdrawal ("ero sola a Firenze, la piú parte del giorno"), and furthers her rejection of a sexual self ("impazzivo di castità; a mio paragone una monaca era una baldracca" [47]). Freedom from domestic tyranny and paternal dependency nevertheless spurs the young artist's creativity. In a matter of months, working hard and alone in a displaced environment, the "ruined" adolescent gives birth to Maestra Artemisia, a new woman with ample will to articulate her desires and a no nonsense attitude to better vindicate her autonomy and defiantly withstand unwanted criticism. "La mia prima cliente me la trovai da me" (47), she boasts in a self-congratulatory tone. Artistic assertion can thus be enjoyed only when Artemisia sets herself free from outside supervision and patronizing postures.

A cursory look at the most important painting of Gentileschi's junior years, the stunning illustration of "Judith beheading Holofernes," makes the viewer immediately realize that this artist is giving free rein to a hatred for men she is no longer able to contain. Banti gives a clear visual description of this canvas and makes it a powerful expression of heroism. ${ }^{8}$ Judith appears as Artemisia's schizophrenic alter ego, as the visual rendering of her creator's "season in hell." The attention of the observer goes to the tenacious cleaving and slitting movement of the sword's being plunged into Holofernes's neck, to the blood's copiously spurting from the bearded victim and streaking into the creases of the bedsheets. Judith's features uncover a determination which was, according to Banti-who clearly wants the painting to be autobiographically important-painfully researched by 
the artist in front of her mirror. The virile Caravaggesque approach is evident in the strength built by a tenebrist work of light and dark on the murderess' arms, one sawing the neck, and the other firmly positioned on the man's face and beard. The fear morbidly spelled in the features of the just-awakened giant positively inscribes the author's creative brutality. "The spectator," writes Germaine Greer, "is rendered incapable of pity and outrage before this icon of violence and hatred, while he is delighted by such cunning" (191). ${ }^{9}$ This is Gentileschi's vindication of the initial sexual aggression against her, the not-so-sublimated reenactment of her first figurative slaughter. She also recognizes that only an innate resilience has secured her psychological survival and thus affirms her newly-found strength by signing her work: "Ego Artemisia / Lomi fec."10 This painting represents, therefore, the embodiment of the author's self-soteriology: "Un'immensa fierezza le gonfia il petto, un'orribile fierezza di donna vendicata in cui trova luogo, malgrado la vergogna, la soddisfazione dell'artista che ha superato tutti i problemi dell'arte e parla il linguaggio di suo padre, dei puri, degli eletti" (54).

Blood equates Artemisia with mythic virgins, with the artist Philomela, for example, who was raped: a common destiny of legendary women. Then, unable to talk and thence to communicate her ordeal, she gave it a political meaning by metaphorically weaving her blood in the purple tones of the tapestry she sent to her sister (Gubar 73-93). In this canvas, blood is generated by a phallus-shaped weapon. Profaned at fourteen and therefore killed as a virginal young woman, wounded at the same time in the role of the socially acceptable daughter-sister-wife, Artemisia keeps bleeding in her heart. In vengeance she allegorically destroys with her brushes the man who destroyed the woman in her. Her sensationalistic, pictorial vendetta becomes by osmosis the collective vengeance of womankind. Banti emphasizes this point with a scene of controlled hysteria. When the painting is finished, Artemisia's female friends first gather around the male model, as if hypnotically summoned. Then, excited by the blood, they stare at him with expressions of paralyzed voyeurs. Finally, spurred by Holofernes's unprotected pose, they mimic his killing in a frenzy. Artemisia arrogantly condemns this "bestiale connivenza di donne' (58), yet she knows that they are her sisters and share with her an identical circumscribed and disilluded destiny. ${ }^{11}$ 
This moment of reckoning and retribution leads to a second therapeutic climax, to a remission of the past and an ironic condolence of men for what they have done to her. "Ascoltava, Artemisia, e perdonava ..." Banti writes, "gli uomini, questi fatali nemici, non le chiedevano piú di giustificarsi, di guardarsi. Erano uguali a lei, ma quasi piú gentili ... . Poveri uomini anche loro, travagliati di arroganza e di autorità, costretti da millenni a comandare" (59). Finally free from hate, Artemisia plunges into a symbolical slumber and then experiences a transfiguring, epiphanic awakening to a new consciousness of the self: " 'Ma io dipingo,' scopre Artemisia, ed è salvata." (59). The notion of renewal is entered in the next paragraph with a pantheistic representation of a peasant ritually harvesting the fields while rain falls to fertilize the soil.

The Maestra's success in Florence is soon soured by the realization that a woman who wants to cultivate her artistic talent is perceived to be a strange human being, a freak. Artemisia is asked whether her confessor has given her special permission to practise her craft and whether she likes to paint sitting down or standing up. ${ }^{12}$ Artistic achievements do not give this painter the credibility and social redemption she so much desires after her days in limbo, because her sex is again an obstacle. For a woman to strive for recognition and intellectual equality beyond an unwritten gender limitation code is dangerous and self-destructive; the image she needs to project is by necessity different from the one of the obedient, submissive, devoted, yet thoroughly childish person the society around her prefers to cultivate. Being in contact with a heterogeneous world, for example, is inherent to pursuing an artistic career. This life, however, continuously puts women in danger of being stigmatized as "easy" because they have the courage to be unconventional and the need to be sociable. If rape denies Artemisia respectability and makes her an anomalous woman, the decision to embrace art in a militant manner foreshadows an even greater ostracism. The Maestra thus painfully decodes the structures of her gendered world only to realize that acquiescence and submission to prevalent mores are always beyond her reach, even if not her conscious desire.

The days in Florence are cut short by Orazio's announcement of his move to England and his request that she return to Rome to live under a different masculine custody. Artemisia finds herself again in 
an unclear and vulnerable position through no fault of her own. Her career as an artist, the societal recognition of her pictorial capability amount to nothing in a patriculture denying the seriousness of her artistic commitment. When a man, the father this time, abandons Artemisia anew, there is no way for her to live peacefully alone at home unless she mummifies herself under another male chaperon. The dilemma seems ludicrous since, according to public opinion, there is nothing in Artemisia still to protect either morally or sexually. Financially she can survive because she has been sufficiently introduced to the Florentine Court to hope for future commissions. Unwillingly but necessarily, Artemisia understands, however, that she has to put aside her aspirations and retrace her way back to Rome. At her arrival in the papal enclave she has two choices: to put herself under the protection of her younger brother or to live with Antonio Stiattesi, the convenient husband Orazio had imposed on her for ersatz respectability (and whom she had to abandon on her wedding day with the Gentileschi's' move to Florence). Antonio is his wife's opposite; he is fearful ("coniglio" was his nickname in youth), unimaginative and pathologically humble. Yet, he can offer masculine protection and curtail social harassment. Artemisia is aware of her possibilities when she unsentimentally ponders each available alternative: "Cosí Artemisia alzò la testa, e fece il conto dei suoi averi: bel viso, bella mano, bella persona, talento, quattro casse, duecento ducati, un marito vivo o morto. . . . In un lampo seppe che il maggiore di questi beni era il marito, condizione perché gli altri fruttassero" (66).

The prospect of a new seclusion proves strangely less fearsome than the Maestra anticipated; her fall turns out at first to be a fortunate one. To her surprise, Artemisia finds in Antonio a shy and affectionate admirer, a silent and caring provider. After her starvation diet in love, she cannot believe her luck: her husband does not belittle or downgrade her, but nourishes her self-esteem. By degrees, affection and sharing relieve her from the emotional isolation of her purgatorial years. The marital status makes her experience at the same time a sense of commonality with other women and of alliance with her gender. As she appropriates a new, comforting domestic image, her mood translates into one of placid warmth: "l'uscio chiuso e il tranquillo compagno le davano un agio, un calore che 
non aveva mai provati, né sola né in compagnia, e neppure con suo padre. Non si ricordava di essere la Gentileschi, pittrice e figlia di pittore. Riscuoteva antichi crediti di benevolenza familiare, di familiare rispetto. Aveva - e la parola continuava a esuadire il suo pensieroaveva un marito" (73). Yet, no matter how much Artemisia claims to be happy with Antonio, the same images of immurement and captivity woven by the author early in the narrative-when she lived under her father's roof in Rome-crowd the pages. Her lodgings, more a cubicle than an apartment, are dimly lit, humid, airless, and dark as a cave ("quella sorte di antro"), the door is always shut. The grotto-like room where she is confined is described as a prison encased inside the cavernous, dingy apartment occupied by her inlaws; her only window being too small and too high. Both stand as metaphors for cellular confinement. ${ }^{13}$ To foster a personal sense of impermanence Artemisia keeps her trunks from Florence locked, her paintings crated, her good clothes neatly packed. The place is as alien to Gentileschi the artist as it is homey to Artemisia the "lost" woman.

In time, the Maestra uncovers two important inner truths. First, she realizes that she can still recover from her sexual ordeal and come to grips with her cracked sexual identity; second, that it is not enough for her to be loved. It is while singing the joys of marital subjugation and infantilization that she unconsciously ends her own claim to bliss with an ambiguous question mark: "Che bella cosa' si estasiava immemore . . . 'che bella cosa appartenere a qualcuno, spogliarsi di sé, esser diversa, irriconoscibile. Che bella cosa?' L'esclamazione diventava interrogativa" (83). This second discovery is bound to cast Artemisia again in the role of the renegade. Conforming to the prevailing gender-related definition of herself without questioning it, enjoying a subservient familiarity can be easy; yet, how valuable? "Questo riflettere e sognare: qui stava il pericolo" (83), Artemisia ponders emblematically. The stultification and suffocation that women often experience in marriage, the feeling of being stalled and redundant, supernumeraries in the only show they are supposed to play, constitute a typical theme in Banti's fiction, one recurrently approached. ${ }^{14}$ Artemisia first thinks that she can combine marriage and artistry by giving them equal time. Her plan is to spend the daylight hours in her brother's studio working at new com- 
missions while reserving the evenings and nights for her ancillary role. Such a flexible tactic does not work. Her priorities polarize: to continue enjoying her present happiness, the Maestra needs to be at home and organize her life around matrimonial responsibilities, yet, to get work from important people, the only ones most likely to pay, she needs to dress well, produce a lot, and live in an enticing studio-apartment. No matter what, her work options are bound to alienate her husband from her because both require him to assume a subordinate role. By losing his power as chief provider, Antonio is bound to lose the financial and moral authority which comes with his position. When Artemisia, temperamentally made for highflung gestures and dramatic choices, accepts her brother's advice to move into a splendid, well furbished apartment, she is aware that her matrimonial days are numbered. Her decision to leave the conjugal domicile on the dawn of the new year poignantly confirms on the symbolic level her need to be(come) adult. However, in choosing art rather than marriage, autonomy rather than obedience, Artemisia is bound to estrange herself anew from her own righteous society. The desire to be a fashionable artist is perceived as at least deviant, her actions are again bound to be judged in exclusive socio-sexual terms. The knights who come to Artemisia's studio look accordingly more at the painter than at her paintings; when former acquaintances stop by, they leave with a typecasted idea of her moral bankruptcy: "quanto alle comari, essi sic ritornarono a casa dicendo che altro che pittura, Artemisia ha trovato il mestiere che fa per lei" (90). She thus becomes the repository not only of eccentric behaviour but also of unfeminine perversity and ingrained selfishness. ${ }^{15}$ Artemisia's new house in Rome, however, is far from the gloomy, stifling and constricting lodgings she inhabits when supervised by men. It is a place of inner and outer freedom, an area of comforting expansion. Its huge rooms and abundantly lit spaces foster a sense of achievement and a mood of optimism. Yet, alone at night, she still needs to confront the demons of her social conscience. Her revolt is studded with a castigating perception of guilt; she feels "infelice e colpevole"; her bed becomes a pit ("parato come se scendesse in un pozzo"), and the labyrinthine rooms of her house give at times no sense of belonging ("non la riconoscono"). When morning comes, however, these oppressive feelings of nothingness evaporate, and self-induced 
misgivings are explained away. Such ambivalences alternate day in and day out as Artemisia fears both the aloneness of the recognized artist and the suffocation of the repressed wife. ${ }^{16}$ Antonio temporarily follows his wife to her new lodgings, soon withdraws into an isolated room and finally walks out. At this point, Artemisia makes her journey away from marital entrapment even more visible. She moves again, this time from Rome to Naples, her escape a definitive one, her choices testifying to a carefully cultivated, virile nature. Whereas after her rape Artemisia wanted to be treated as a man because society was unwilling to honor her as a woman, now she wants to be dealt with in masculine way because she knows that she is as good as her male colleagues in the expression of their common aesthetic tradition. ${ }^{17}$

The novel could end at this point with a view of Maestra Gentileschi having somehow completed her Bildung, although more out of emargination and rebuttal than of systematic education. She has rebelled against her world and experienced pain, loneliness and alienation. She has pursued success while searching for her true self. She has outlived some of her illusions, verified others, and mapped her personal destiny while maturing in the process as a human being and as an artist. The society which has consistently antagonized and buffeted her, the neighbours who have judged her morality along sexbiased lines, can in time, perhaps, reaccept her, provided her success remains steady. She has assertively re-appropriated her name and, according to art historians, it is at this point in life that Artemisia stops signing herself with her father's patronimic Lomi and assumes her own: Gentileschi. At the same time her Neapolitan colleagues acknowledge her artistic worth and elevate her form Maestra to the status of "virtuosa." Yet the story cannot end here. This painter's peace with her environment is, at best, tentative.

An important change takes place at this point in Artemisia's life. After giving birth to herself as the best female painter in Naples, she gives birth biologically as well. Although alone, Artemisia does not view the nine months of female generativity in negative terms and seems truly to enjoy the new, unusual kind of artistry. Parturition finds her as content and placid as her black and white cat in Rome delivering a new litter: "Era un sentirsi protagonista, ma umilmente, alle prese con un male leggendario che veniva di lontano anche se 
le nasceva di dentro" (101). She realizes that the period of confinement her pregnancy requires, rather than confining her outside society, makes her belong to it. She contentedly plays up therefore to the cliché of the pregnant woman and to the myth of the selfless, self-abnegating mother. The "virtuosa" is destined to fail, however, even in the maternal role, as if the production of the creative artist and the reproduction of the mother can only be experienced antithetically in a woman. The fiasco is not necessarily due to personal shortcomings. Artemisia soon finds that she cannot be too emotionally accessible to her daughter because her nurturing would be perceived as plainly womanish among the artists and friends who patronize her studio. A father would not be reproached for being affectionate toward his offspring, yet a woman who has to survive in a world of men finds that maternal attachment is easily taken for weakness, personal solicitousness for visceral calling. As a result of her firmness daughter Portiella will in time reject her. Portiella cannot reconcile in fact the image of this ambitious, self-possessed, aggressive progenitor with that of the angelical mater familias dutifully propagated by her nuns at school. If, for once, Artemisia's morality as a woman is not questioned, it must be her morality as a mother that is dogmatically challenged. Her friends unendingly eavesdrop on her personal life to provide eventually their rationalization of feminine inborn evil. Blaming success for the "virtuosa's" lack of maternal tenderness, her colleague Stanzione voices the salacious gossip: "questa è una donna che non ha viscere, non conosce i dolori del parto, il sangue fatto latte; questa è un'orsa, una fiera. Insinuazioni che non dispiacciono alla pittrice quando gliele riportano, anzi la esaltano e l'aiutano ad apparire eccezionale: una che si è lasciata alle spalle tutti gli affetti e persino il vanto delle femminili virtú, per seguir la pittura solamente" $(105) .^{18}$

In Naples, the Maestra finds that survival without masculine protection is difficult and conformity to the status of the fashionable volcanic artist even more taxing. Her bombastic attitude when receiving guests and her narcissistic pleasure in basking in the homage paid to her, no matter how artificial, protect an exterior facade. Inwardly, however, she becomes vulnerable. Her room high on top of stairs is now both physically and metaphorically isolated: the ivory tower of the individualist in search of an autonomous self through 
confinement. Loneliness makes Artemisia both aggressive and defensive. She desperately searches for examples of women whose conduct is similar to her own, women whose intellectual alliance would strengthen her sense of worth and whose gender identification would lend her a degree of self-assurance. But there are no secular precursors, no role models; there is no matrilineal cultural past to retrieve. ${ }^{19}$ "Questa è una donna," Banti writes, "che in ogni gesto vorrebbe ispirarsi a un modello del suo sesso e del suo tempo, decente, nobile; e non lo trova. Una immagine con cui combaciare, sotto il cui nome militare: tanto occorre ad Artemisia sui trentatré anni" (109-10). The Maestra's wish is not to imitate others, but to discover in her gender a successful example of survival and recognition, yet she finds no women who have happily come of age and enjoyed civic approval while defying conventions and questioning the brainwashing exercises upon their sex. Grace Stewart states: "Whereas the male artist can identify with traditional mythic heroes without jeopardizing his self-image or his sexual identity, the female artist is burdened by the heritage of patriarchal myths in a society which arbitrarily excludes her from various experiences, sets her on a pedestal or in a pigsty, and otherwise causes ambivalence about her self-image. ${ }^{, 20}$ When Artemisia eventually finds by chance the woman whose intelligence and worth mirror hers, she mentally agrees on the larger truth of her alter ego's lapidary sentence: "Nessuna donna è felice se non è sciocca" (165). Artemisia Gentileschi, who is intelligent, brave, ambitious, and autonomous, can confirm this statement with her own experience: happiness is always somewhere else. Friendship with female artists seems also impossible because, as she finds out, women have been socially conditioned for such a long time to see enemies among themselves and to uncompassionately fight for man's approval and love that they are unable to offer each other true solidarity. Their lack of trust makes them vulnerable; sexual anxiety and collective submission give their lives a sense of mortifying loneliness. When Annella De Luca, a young "virtuosa" in Naples, comes to visit Artemisia's fashionable studio, she behaves like a primadonna to antagonize her female colleague and to further please the men in the room. In a virulent tone Artemisia indicts the whole womankind for making itself victim to such a range of masculine manipulations: "Nessuno le può far male quanto una donna. Questo 
avrebbe dovuto spiegare a quei signori che forse si sono divertiti ai contrasti delle due virtuose. 'Vedete queste femmine' avrebbe dovuto dire, 'le migliori, le piú forti, quelle che piú somigliano ai valentuomini: come son ridotte finte e sleali fra loro, nel mondo che voi avete creato, per vostro uso e comodità. Siamo cosí poche e insidiate che non sappiamo piú riconoscerci e intenderci o almeno rispettarci come voi vi rispettate'" (118-19). There is, moreover, no positive adult female image in the whole novel to set an example for Artemisia. All women betray her. Her mother fails her by dying too early, her stepmother for running away when she most needs her guidance, her chaperon for manipulating and misusing her inexperience, and her daughter for her conventionality. All men as well, apart from her sympathetic brother, betray Artemisia. Agostino chiefly deceives her with his circumventing ways, but so does her father who selfishly withdraws his affection and protection when it pleases him, and her husband who refuses to recognize her independent selfhood. Having been victimized by others, Artemisia starts to tyrannize her female models in reprisal. She feels men tend to patronize or censor her because she is a woman and, in half-conscious retaliation, she sourly dismisses women for not meeting her expectations. Her irritability becomes the metonymical substitute for her anger and insecurity; her attitude turns into one of "orgoglio e sprezzo, con un pizzico di protervia" (124). She apologetically defends her artistic achievements and querulously complains that it is because of her work: "se chiedo ducento scudi per otto figure il principe Ruffo me ne offre cento: perché sono una donna e il merito non vale" (117). She throws color on her canvases and augments the strength in her women's muscular, masculine arms. This public posturing hides, however, a painful sense of fragmentation, an ingrown feeling of anxiety about her own artistic worth. Yet, when she puts the mask aside and shyly asks for protection, men do not heed her call; when she attempts to circumvent her loneliness with a lover, she ends feeling both insecure and guilty for having somehow conformed to the idea people have of her: "la Gentileschi è donna calda, la pratica chi vuole" (113). In time, as the years increasingly mirror her physical decadence, Artemisia begins to feel morbidly persecuted. The days of alienation and discrimination make her slightly paranoid about supposed friends and enemies; the stamina necessary 
to appear strong in public takes a radical toll in the "piega di delusione costante all'angolo delle labbra" (123-24). She seems to suffer "delusions de grandeur." Would it have been better to have acquiesced in the cultural code, remained at home, propped up a sinking marriage, and embraced a wifely role? The text offers numberless images of loss, weariness, and futility.

It is at this point in the narrative-a moment of stasis which forewarns of the approaching end of youth-that Banti provides her heroine with a moment of rebirth and an occasion to re-define herself. She does it by reuniting father and daughter after a twenty-five-year lapse. In order to meet him in London, Artemisia embarks in the longest journey of her lifetime, this one too leading from darkness to light, form depression to some emotional security. ${ }^{21}$ Her first journey was figuratively an escape from a prison-like environment, Rome, where she had no freedom or respect, to a place of satisfaction, Florence, which enable her to focus on her artistic potential. Her second was a quest for maturity, an evasion of an untenable marriage into adulthood, and, as in many other examples in women's literature, this choice excluded her from society for the second time. This journey is again a demystifying one as Artemisia, "donna virile," goes back to reform a primordial nucleus with her father and to test the wisdom of her choice to be an artist. It is only when she can find a place within a male text and gain recognition from the first man who rejected her that Artemisia can make her peace with the past. This trip leads her also to recognize her own mortality. In many ways, her journey is leading toward death or reconciliation with dying. She leaves Italy as if she were never to come back. Tempests and high seas fill her trip. One day, during a stop in a French tavern, she fears the plague and lies in bed waiting for the end. Then, in England, the intimations of mortality become more poignant when Orazio falls into his final hours.

At her arrival in London, Artemisia finds herself exiled both linguistically and artistically. On the emotional level, her father's indifference makes her feel like an outcast. Needing his approval, she grows neurotic, reverts to acting childish, and starts to knit compulsively. Yet, unexpectedly, a second miracle happens. One day Orazio comes to his daughter's studio to examine her work, as he did one night in Rome so many years before, and, after some brooding, 
he looks up and lends her his autocratic and rare praise. A feeling of elatedness overwhelms the Maestra now as father and daughter at last speak the same language. Artemisia feels she is no more the "lost" woman, a being to judge by implication, nor the "daughter," a person to protect or to chastise, but the proficient co-worker, the androgynous artist: "Una felicità intoccabile in cui l'onore cosí presto perduto vien restituito a un animo che già cedeva. Non importa esser stata donna, più volte sconsigliata, due volte tradita. non c'è piú dubbi, un pittore ha avuto nome: Artemisia Gentileschi" (196). Her quest for autonomy is complete now. She is therefore able to answer her father's artistic questions in a masculine way, her posture inscribing her new self-consciousness: "Il pugno della donna si appoggia al fianco virilmente; tutto il corpo compresso nella rigida ampiezza dei panni, sfoggia gesti poco femminili, ma cosí innocenti" (196). By re-proposing herself as "innocent" in front of Orazio, she can propose herself as whole, that is, synchronically as Artemisia, as Maestra and as "virtuosa," and link her prelapsarian past to her creative, self-assertive and mature present.

It is only when Artemisia feels her identity confirmed by her unexpected success in the English court and reconfirmed by Orazio's nod of approval that she can attempt its artistic representation. In "La Pittura" we have a self-portrait of Gentileschi in the act of being what she is, a painter. As she sketches, the artist represents herself allegorically, thus following the iconographic tradition of her tie in which females symbolized Art. ${ }^{22}$ It is while she outlines the features of a woman, however, that other shapes seem to come into the canvas, other diffuse female facial contours seem to appear in the artist's representation of herself. At the beginning, Banti tells us, Artemisia is not aware of her ambiguous, multiple renderings; her brushes follow her memory. She soon realizes, however, that the dark woman taking shape in her canvas with her vaguely unkept hair, virile fingers and in oblique position within a violet and green background, resembles somehow the "virtuosa" Annella de Luca, the rival artist who scorned her once in Naples only eventually to beg for friendship. Annella was subsequently murdered by her jealous husband. It is in blood then that Artemisia starts her career and in blood that she seemingly ends it, the blood of Holofernes not having spared that of Annella, Judith not having transferred the power of her courageous 
reprisal to her modern sister. The concentrated and vaguely cerebral facial expression in the painting illustrates, however, more than the particular physiognomies of Artemisia and Annella. It stood then, and it stands now, as a collective representation of female "heroinism," as an icon of militant self-assertion. Artemisia Gentileschi can finally paint herself in toto-as a painter, a woman, a colleague, and even as a philosophical symbol-because, by splitting herself into more than one woman, she can reconfirm her gender identity and reaccept her female heritage. ${ }^{23}$ For years she had rejected women and scorned their repressed ways; now, however, her maturity and newly-found feelings of belonging make her communicate and empathize with them. By recalling her femaleness, Artemisia can now come to terms with her own nurturing qualities and reunite the artist and the mother in her. She starts to draw from memory the head of a young maid met in France, Delfina, a perfect surrogate daughter for a woman whose maternal instincts were often stifled by Portiella's rebuttals and her friends' dismissal.

"La Pittura" carries a meaning well beyond the aesthetic one. "Ritratto o no," Banti writes, "una donna che dipinge nel milleseicentoquaranta è un atto di coraggio, vale per Annella e per altre cento almeno, fino ad oggi" (213). "Vale anche per te," admonishes Artemisia from the page to her creator Banti, who finds in this expression of sororal bonding the spur to continue her own task as writer. The sentence calls back to memory Virginia Woolf's A Room of One's Own, which Banti was to translate into Italian a few years later. In Artemisia Gentileschi, painter and daughter of a painter, it is possible to hear the emblematic cry of Judith Shakespeare, a hypothetical poetess and sister of a poet. ${ }^{24}$ Judith kills herself one winter night for having been rejected by a society unwilling to understand or accommodate her diversity; Artemisia truculently survives. "La Pittura" is her answer to a culture which casts away the female intellectual because it is unable to classify her. It is her response to a world bent on uniformly institutionalizing patriarchal ideology and on furthering female submission. It is her elegy to all women who fight public ostracism and professionalize their creative aspirations no matter what the cost of their choices. It is her visual rendering of that first cry of self-discovery in Florence: "Ma io dipingo." It is an emphatic story of survival where waste seemed unavoidable, a 
narration of courage when personal fragmentation had been itemized by too many punishing moments of dispossession. In the intense expression of the sitter in "La Pittura," as before in Judith's determined face, a feminocentric world is defiantly celebrated.

This pictorial statement concludes our extended Kunstlerroman. The chronological ending, however, is left uncharted both by the author, who leave her protagonist in a metaphorical slumber, and by art critics, who have no uncontroversial documentation available to set a specific date for her death. Yet, Maestra Gentileschi can rest vindicated, her self-mythologizing philosophy permanently inscribed in a canvas in the Queen's property.

Duke University 


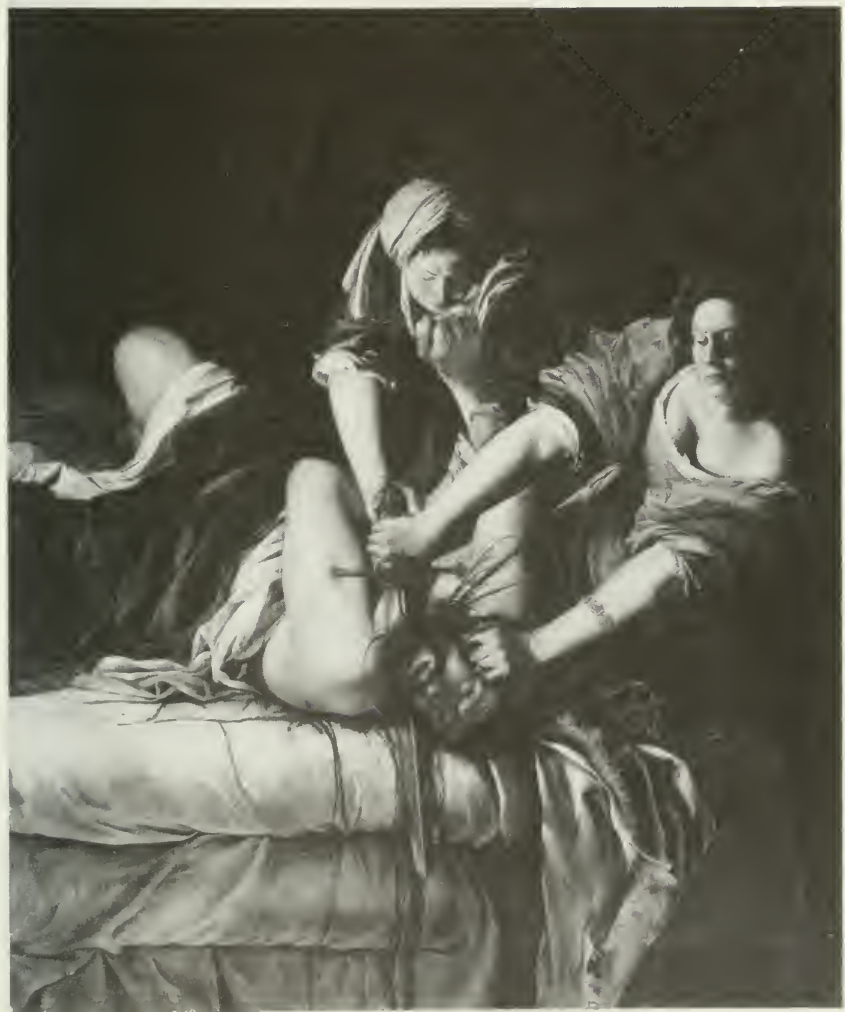

Artemisia Gentileschi, Giuditta e Oloferne. Courtesy of Galleria degli Uffizi, Firenze. 


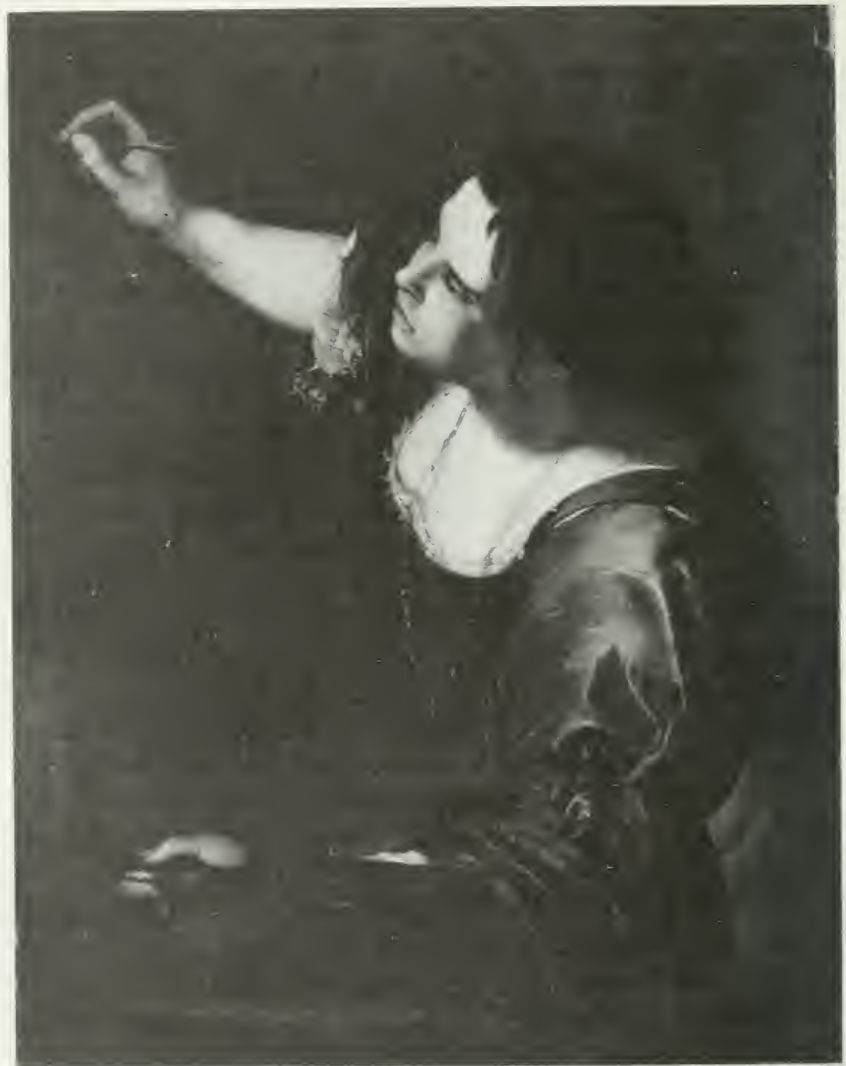

Artemisia Gentileschi, Self-Portrait. Copyright reserved to Her Majesty Queen Elizabeth II. 


\section{NOTES}

1 Anna Banti, Artemisia (Milano: Mondadori, 1953), preface. Page numbers will be hereafter given parenthetically in the text. Banti also wrote a play based on this novel, Core Savella (Milano: Mondadori, 1960)

2 Most of the new information on the Gentileschi has been put forward by Banti's husband, art critic Roberto Longhi. He effectively rediscovered this family of painters in his seminal study. Banti also uses the study by Bizoni. This book is unavailable, but Banti possesses a rare copy of it as she states in Opinioni. Other studies on Gentileschi are those of Bissell and of Moir. Germaine Greer has recently recognized her sisterhood in this spiritual orphan of the seventeenth century ostracized by society and crippled by public opinion in The Obstacle Race. The question of Artemisia Gentileschi's birth has recently been settled with 1593 as a more likely date than 1598 . As for her death, it is set somewhere between 1652 and 1653 .

3 See also her "Bildung in Ethnic Women Writers"; Hirsch, and Morgan.

4 For many centuries there was no art academy open to women, therefore whatever artistic education they could get would necessarily have to come from home (a father, husband, brother being an artist in his own right and letting everybody in the family help). Men often signed women's works in order to have a better chance to place them. For more on the subject, see Nochlin.

5 Artemisia's rape took place in her own house, with Tuzia away, in a moment when, like Clarissa Harlowe, she was partially unable to defend herself (she had complained of fever). The records show that she used a knife for self defence and wounded her assailant. Rape, or a tainted respectability, was at that time the common lot for women painters. Just to limit ourselves to the few female artists whose names are known to us today, Onorata Rodiani was brought to trial for killing her rapist, Properzia (De) Rossi came into the annals as a courtesan, even unreproachable Sofonisba Anguissola was chastised for displaying some sort of sexual behavior in her second, "senile" marriage.

6 The trial records are available for consultation in Rome. They are grouped in a file of the year 1612 titled "Stupri et Lenocinij — Pro Curia et fisco con Augustinum Tassum Pictorem." The records were recently published by Menzio. During the formal hearing Tassi refused reparation and claimed that he never had any intention of marrying Artemisia because he was already married in Pisa. Moreover he hinted at the possibility that Artemisia was sharing him with another fellow painter. The Court did not accept his argument and he spent eight months in prison. Tassi was not new to sexually-related lawsuits. Shortly before the Gentileschi's trial, he had been sentenced for having repeatedly committed incest with his-sister-in-law. In cross examination even his own sister refused to defend him. Agostino must have had a truly interesting personality, however, if Orazio Gentileschi could in time forget the uproar caused by his daughter's ordeal and revive his friendship with this unreforming rake. For an interesting study of Agostino Tassi, together with an 
undocumented denunciation of Artemisia, see Rudolf and Margot Wittkower $162-64$.

7 Garrard "Artemisia e Susanna" 58 links to this period Artemisia's painting "Susanna and the Elders." Here the heroine, contrary to common male renderings of the subject, expresses in her face and body the fear of rape, the anguish of a woman "faced with a choice between rape and slanderous public denouncement."

8 For a definition of "heroinism," see Trilling.

9 One has only to see other renderings of the same subject to realize how shockingly personal is this canvas. The theme was quite popular at the time. Apart from men, there were two women painters who painted "Judith and Holofernes": Elisabetta Sirani and Fede Galizia. Their rendering of Judith is passive and subdued. In both canvases Judith looks away from the scene of the murder and hardly seems to possess the bodily strength necessary to kill a giant. For more see, for example, Petersen and Wilson 26-30.

10 The inscription appears at the bottom of the canvas. Lomi was Orazio's family name, definitely more known in Tuscany than Gentileschi. See Bissell.

11 All considered, Gentileschi does not have Judith commit the homicide alone, but has her helped by a servant each time she recreates the subject. As of today there are six "Judith and Holofernes" by Gentileschi spread around the world. Naples has two, and one each have as far distant cities as Florence, Malaga, Milan and Detroit. The trial records also mention a "Judith" which Artemisia was painting at the time of the rape and which Tassi took away and refused tor retum. This painting has never been found. Artemisia's artistic fame is usually linked to gory representations. In the "Judith with her Midservant," now in Milan, she signs her name in the bloodied sword. While her entire religious work is manneristic and unkindled, she is very good in representing non-moral themes. Especially interesting are those canvases in which strong willed, "lost" women are either heroically poised at the center of the representation (as in "Cleopatra" and in the "Penitent Magdalen"),or are seen reacting with each other (as in the many Judiths and in "David and Bathsheba"). Gentileschi is also well known for portraitures of women of her time. She also portrayed powerful men, but one has to take into account the fact that not many men would have commissioned a woman for their own portraits. Correspondingly, not many Church officials would have accepted laywomen' religious entries for church decoration.

12 For a thorough study of the a-typical images creative women project, see Gilbert and Gubar. The stereotypes associated with women painters (female artists as being non-creative, imitating, delicate, narcissistic, emotional, intuitive vs.- male artists as being powerful, bold, assertive, creative, and logical) are discussed by Nemser 156-67.

13 Banti uses a visual vocabulary to describe a dinner in the Stiattesi family: the food thrown from above through a hole on the wall and the ravenous expression of the people at the sight of meat make these interiors literally 
look like the antechamber of hell. This passage, like many others in the novel, shows a peculiar pictorial technique which Banti may derive from her thorough knowledge of painting. Citati 7526-37 notices the same chiaroscuro effects of the physiognomies, the Modigliani-like facial expressions of the characters in an earlier collection of Banti's stories, Il coraggio delle donne.

14 For a book-length study of Banti's fiction see Biagini. shorter studies are those of Barberi-Squarotti and Contini.

15 Artemisia was also considered strange for dressing as a man in Rome in order to avoid harassment during her daily carriage trips to her brother's study. By using transvestism Banti says a lot about the paradoxical power clothes dictate for gender definition. In this role Artemisia is a precursor of 19th century painter Rosa Bonheur, who used to crossdress when she needed to study her daily subjects closely and more realistically.

16 Pratt 29 writes: "The novel of development portrays a world in which the young women hero is destined for disappointment. . . Every element in her desired world-freedom to come and go, allegiance to nature, meaningful work, exercise of the intellect, and use of her own erotic capabilitiesinevitably clashes with patriarchal norms. Attempts to develop independence are met with limitation and immurement, training in menial and frustrating tasks, restrictions of the intellect (lest she perceive her status too clearly), and limitation of erotic activity."

17 All historical accounts show the appropriateness of Gentileschi's move given the wide success she enjoyed once there. Artemisia's influence in Naples, according to major art critics, has been second only to that of Caravaggio. Although conscious of her sex, Gentileschi painted all along standard subjects of her age. She wanted to be recognized as equal among men rather than be patronized as distinctly female. An issue which is currently being debated by art historians of both sexes is whether women use a markedly female imagery in their works. Feminists tend to dismiss the issue. Russell 474 writes: "This 'hands-off' attitude is easily understandable. Since the Renaissance, women artists have not wanted to be picturesque tributaries to the mainstream of the visual arts but part of the mainstream, recognized for the merit of their work and not their sex."

18 One is reminded of the painful choice of Edna Pontellier regarding her children: "I would give my money, I would give my life for my children; but I wouldn't give myself," in Chopin 79.

19 "I look everywhere for grandmothers and see none," complained Elizabeth Barrett Browning more than two centuries later (232).

20 For Gilbert and Gubar 49 the female artist can begin her struggle for selfdefinition "only by actively seeking a female precursor who, far from representing a threatening force to be denied or killed, proves by example that a revolt against patriarchal. . . authority is possible."

21 Her quest follows in many ways the pattern itemized for male heroes by Campbell. The outline has recently been retraced in women's narrative by 
Pearson and Pope.

22 The painting was valued L. 50 in 1649 by the Trustees of Charles I and titled: "Artemisia gentilesco done by her selfe." For more on the subject, see Levy 79-80, and Garrard "Artemisia Gentileschi's Self-Portrait" 97-112.

23 In many ways she recalls her mythic namesake Artemis, the goddess of wilderness, who stands for independent selfhood, assertive sisterhood, and virginal (healthy) sexuality.

24 Virigina Woolf 85-86 writes: "Any woman born with a great gift in the sixteenth century would certainly have gone crazed, shot herself, or ended her days in some lonely cottage outside the village, half witch, half wizard, feared and mocked at. For it needs little skill in psychology to be sure that a highly gifted girl who had tried to use her gift for poetry would have been so thwarted and hindered by other people, so tortured and pulled asunder by her own contrary instincts, that she must have lost her health and sanity to a certainty."

\section{WORKS CITED}

BANTI, A. Il coraggio delle donne. Firenze: Le Monnier, 1940, . Artemisia. Milano: Mondadori, 1953.

. Corte Savella. Milano: Mondadori, 1960. . Opinioni. Milano: Saggiatore, 1961.

BARBERI-SQUAROTTI, G. "Appunti intomo alla narrativa di Anna Banti." Letteratura 7 (1959): 114-22.

BARRETT-BR.OWNING, E. The Letters of Elizabeth Barrett-Browning. Ed. F.G. Kenyon. Vol. 1. New York: McMillan, 1897.

BIAGINI, E. Anna Banti. Milano: Mursia, 1978.

BISSELL, W. "Artemisia Gentileschi: A New Documented Chronology." Art Bulletin 50 (1968): 153-67.

BIZONI, B. "Europa milleseicentosei." Preface to Diario di viaggio del marchese Vincenzo Giustiniani. Milano: Longanesi, 1942.

CAMPBELL, J. The Hero with a Thousand Faces. Cleveland \& New York: Meridian Books, 1956.

CITATI, P. "Stile e tecnica narrativa di Anna Banti." Novecento. Ed. G. Grana. Milano: Marzorati, 1980: 7526-37.

CHOPIN, K. The Awakening. New York: Avon Books, 1972.

CLARK, M. G. and D. J. LEWIS. Rape: The Price of Coercive Sexuality. Toronto: U of Toronto P, 1977.

CONTINI, G. "Parere ritardato su Artemisia." Altri esercizi (1942-1971). Milano: Einaudi, 1972: 173-78.

GARRARD, M. D. "Artemisia Gentileschi's Self-Portrait as the Allegory of Painting." The Art Bulletin 62 (1980): 97-112.

"Artemisia e Susanna." Feminism and Art History. Questioning the Litany. Ed. N. Broude and M. G. Garrard. New York: Harper \& Row, 1982. 
GREER, G. The Obstacle Race. The Fortunes of Women Painters and Their Work. New York: Farrar Straus Giroux, 1979.

GILBERT, S. M. and S. GUBAR. The Madwoman in the Attic. The Woman Writer and the Nineteenth-Century Literary Imagination. New Haven \& London: Yale U P, 1979.

GUBAR, S. "The Blank Page and the Issue of Female Creativity." Writing and Sexual Difference. Ed. E. Abel. Chicago: U of Chicago P, 1982: 73-93.

HIRSCH, M. "The Novel of Formation as Genre: Between Great Expectations and Lost Illusions." Genre 12 (1979): 293-312.

HOOVER BRAENDLIN, B. "Alther, Atwood, and Gray: Secular Salvation in the Contemporary Feminist Bildungsroman." Frontiers 4 (1979).

. "Bildung in Ethnic Women Writers." Denver Quarterly 17 (1983): 75-87.

LEVY, M. "Notes on the Royal Collection. II. Artemisia Gentileschi's 'SelfPortrait' at Hampton Court." Burlington Magazine 104 (1962).

LONGHI, R. " Seicento pittorico italiano." L'Arte 19 (1916): 245-314.

MENZIO, E., Ed. Artemisia Gentileschi / Agostino Tassi. Atti di un processo di stupro. Milano, 1981.

MOIR, A. The Italian Followers of Caravaggio. Cambridge, Mass. : Harvard U P, 1967.

MOERS, E. Literary Women. New York: Doubleday, 1976.

MORGAN, E. "Humanbecoming: Forms and Focus in the Neo-Feminist Novel." Images of Women in Fiction. Feminist Perspectives. Ed. S. Koppelman Cornillon. Bowling Green: Bowling Green Popular Press, 1972: 183-205.

NEMSER, C. "Stereotypes and Women Artists." Feminist Collage. Educating Women in the Visual Arts. Ed. J. Loeb. New York \& London: Columbia U P, 1979.

NOCHLIN, L. "Why Are there no Great Women Artists?" Women in Sexist Society. Ed. B. Moran. New York: Basic Books, 1971: 344-66.

NOZZOLI, A. Tabú e coscienza. La condizione femminile nella letteratura italiana del Novecento. Firenze: La Nuova Italia, 1978.

PETERSEN, K. and J. J. WILSON. Women Artists. Recognition and Reappraisal from the Early Middle Ages to the Twentieth Century. New York: New York U P, 1976.

POPE, K. The Female Hero in American and British Literature. New York \& London: R. R. Bowker Co., 1981.

PRATT, A. Archetypal Patters in Women's Fiction. Bloomington: Indiana U P, 1981.

RUSSELL, H. D. "Art History." Signs 5 (1980).

STEWART, G. B. "Mother, Daughter and the Birth of the Female Artist." Women's Studies (1979).

TRILlING, D. "The Liberated Heroine." Partisan Review 45 (1978): 501-22. WITTKOVER, Rudolf and Margot. Born under Saturn. London: Weidenfeld \& Nicholson, 1963.

WOOLF, V. A Room of One's Own. New York: Harcourt Brace \& Co., 1930. 